\title{
Estonian School Culture - Endeavor for Learning Organisation
}

\author{
Ene-Silvia Sarv
}

\begin{abstract}
School climate and school culture form an environment for pupil and teacher well-being and development. Part of school culture is the organisational culture of school. Concepts of learning organisation, knowledge creation, and knowledge management are applied to understand differences in school organisational culture as perceived by teachers in a survey conducted in 2004 at Tallinn University within the framework of the project 'School as a developmental environment and pupils' coping.' The project arose from the need to prevent pupils from dropping out of school in Estonia. The main hypothesis was that by becoming aware of and modifying a school's social climate, stakeholders can support, or not, pupils' academic success. Results allowed identification and description of types of schools and teachers in Estonia. The important conclusion of the project was that the type of school culture, especially the school value system and teacher attitudes toward pupils, influence pupils' optimistic acceptance of life, well-being, and academic coping. The type of school known as a "learning developing school" supports pupils in coping the most.
\end{abstract}

Keywords: school, teacher, learning organisation, school culture

\section{Introduction and conception}

Teachers, schools, and pupils are mostly intertwined for nine to twelve years. Teachers and schools preserve and transmit culture, traditions, values, and knowledge. This can be a solid support point or a possible risk factor for children, parents, and society. If school climate and school culture are not perceived as helpful aid by students, the result might be school avoidance and dropping out. ${ }^{1}$

Rapid global changes at the end of the $20^{\text {th }}$ century led to the idea that the era of industrial growth was being replaced by an information society through the "postmodern moment", "knowledge society", "sustainable society", but also by "risk society". Sustainability, lifelong learning, learning organisations and learning societies, and management, creation, and innovative use of knowledge became important as concepts in philosophy and research and as

1 V.-R. Ruus, et al., 'Students' Well-being, Coping, Academic Success, and School Climate,' Social Behavior and Personality, vol. 35, no. 7, 2007, pp. 919-936.

2 J.-F. Lyotard, The Postmodern Condition: A Report on Knowledge, Minneapolis, University of Minneapolis Press, 1989, p. ix; R. Usher, R. Edwards, Postmodernism and Education, London, Routledge, 1994, pp. 7-10.

3 U. Beck, Risk Society, London, Sage, 1992. 
practice. In this context, emphasis was placed on the changing role of schools and teachers in a knowledge-based learning society. ${ }^{4}$

Sustainability was related to inclusiveness and innovation, taking into account long-term results. ${ }^{5}$ From this, it followed that school needed to prepare people for participation in a knowledge-based society.

The above dimensions - inclusiveness and innovation - influenced everyday life in school and the school climate and culture. Continuous and rapid changes challenged the traditional role and nature of school and the heritage of the authoritarian regime. Changes appear in an atmosphere that result from the activities and relationships between teachers, pupils, and school leaders. Concurrently, change appears in documents regulating school life - school curriculum, strategic development plans, job descriptions and rules, and even more so in values and traditions.

School culture is often defined as the carrier of historically transmitted meanings that include norms, values, beliefs, traditions, and myths understood by members within the school community that shape thoughts and activities. The most important areas are educational, pedagogical, learning, and organisational cultures. Aspects such as moral education, a sense of belonging, fraudulent culture, teachers' implicit theories (as part of culture, as mind models) are also distinguished. Simply put, school culture describes both the general in all schools and the school's uniqueness. ${ }^{6}$ So, school culture is always at work, either helping or hindering learning. It influences every decision and action, from the leadership style of the principal to the way teachers choose curriculum materials and interact with pupils.

The concepts of school culture closely or partially overlap with the school climate and school ethos. School culture as a concept and phenomenon is a common element in the development of two approaches - cultural (a broad general concept) and organisational (as an institutional, structural, and procedural whole for the purposeful targeting of people).

A special dimension of school culture has been pointed out by researchers and philosophers (e.g. James W. Botkin and Carl G. Jung) - a dark, subconscious "shadow" side: evil, mistakes, fears... This negative side of culture is not only

4 G. Raagmaa, E. Terk (eds.), Eesti tulevikustsenaariumid: üleriigiline territoriaalmajanduslik planeering 'Eesti 2010' [Estonia futures scenario 'Estonia 2010': nationwide economic-territorial planning], Tallinn, Tartu, Eesti Vabariigi Keskkonnaministeerium, Eesti Tuleviku-uuringute Instituut, 1997; K. Loogma, E.-S. Sarv (eds.), Eesti ühiskond ja haridus - 2015 [Estonia society and education - 2015], Tallinn, Eesti Haridusfoorum'98, Avatud Eesti Fond, 1998; R. Vilu, E.-S. Sarv, 'Kool ja infoühiskonna haridusfilosoofia' [School and the philosophy of information society], in S. Maanso (ed.), Eesti haridusvalikud XXI sajandi lävel: EHF 1.-3. november 1996: ettekannete ja sõnavõttude kogumik [Estonia - educational choices at the beginning of $21^{\text {st }}$ century: EEF 1-3 November 1996, presentations], Tallinn, Eesti Haridusfoorum, 1997, pp. 56-68.

5 SHELL, 'Global scenarios 2025'. Available: http://www.shell.com/home/content/aboutshell-en/ our_strategy/shell_global_scenarios/previous_scenarios/previous_scenarios_30102006.html (accessed 12.01.2008).

6 H. Beare, B. J. Caldwell, R. H. Millikan, Creating an Excellent School, London, Routledge, 1994, pp. 172-179. 
hidden but is a taboo that is not recognised, which is preferred not to be seen or spoken about. ${ }^{7}$ In terms of sustainability of the organisation and especially its educational consequences, the shadow school culture and negative subcultures deserve serious study and awareness in schools. ${ }^{8}$

The first analysis of the application of learning organisation and school culture ideas in Estonian schools was completed in 2001. ${ }^{9}$ Development plans of 60 schools were analysed. Content analysis of structural elements of the development plans provided an overview of all aspects of school development, systematised them, and linked them with the main ideas of sustainability and development of education.

Universal dimensions were used to sketch the model of school types:

- Orientation towards coherence vs. alienation and competition, which simultaneously recognises diversities and different ways of thinking (as a potential origin of creativity); and

- Openness, innovation, level of aspiration and orientation towards humanistic values, i.e. dynamism, creativity, and innovation vs. closure, conservatism, avoiding challenges, orientation for immediate benefit, stagnation, and conservatism. ${ }^{10}$

It should be emphasised that in 2001, school development plans already included aspects of the key areas of learning organisations and knowledge management and viewed teachers as active and involved subjects/agents in school development. Plans continued emphasis on participation and democratisation, which was launched in 1987-1988 and continued in the curricula of 1996 and 2002. ${ }^{11}$ Four types of school development plans included winning-competing, value-/human-centered, active learning organisation features, and conservativeformal-passive. Each type took a different approach for a pupil (and teacher) development environment. ${ }^{12}$

\footnotetext{
7 J. W. Botkin, Smart Business: How Knowledge Communities can Revolutionize Your Company, New York, The Free Press, 1999, p. 151.

${ }^{8}$ H. Beare, B. J. Caldwell, R. H. Millikan, Creating an Excellent School, London, Routledge, 1994, pp. 172-179; D. H. Hargreaves, 'School Culture, School Effectiveness and School Improvement,' School Effectiveness and School Improvement, vol. 6, no. 1, 1995, pp. 23-46.

${ }^{9}$ E.-S. Sarv, 'On Structure, Content and Typology of School Development Plans in Estonia,' in S. Priimägi, E.-S. Sarv (eds.), The Opening World: Changing Educational Environment and Teacher Training, Tallinn, Tallinn Pedagogical University, 2002, pp. 78-105.

${ }^{10}$ K. Loogma, R. Ruubel, V. Ruus, E.-S. Sarv, R. Vilu, 'Estonia's Education Scenarios 2015, The $21^{s t}$ Century Learning Initiative Journal, May, 1998. Available: //www.21learn.org/test/ newslet.html (accessed 18.02.2018)

${ }^{11} \mathrm{~J}$. Jaani, 'Õppekavakogemus õpetab’ [Curriculum-experience gives a lesson], Haridus [Education], 2004, no. 11, p. 14.

${ }^{12}$ E.-S. Sarv, 'On Structure, Content and Typology of School Development Plans in Estonia,' in S. Priimägi, E.-S. Sarv (eds.), The Opening World: Changing Educational Environment and Teacher Training, Tallinn, Tallinn Pedagogical University, 2002, pp. 78-105.
} 
In 2004, a complex survey was conducted on coping of Estonian schools, pupils, and teachers. ${ }^{13}$ The study used a socio-ecological approach based on theories about the development of pupil and teacher abilities to cope with school conditions ${ }^{14}$ and school as a learning organisation. ${ }^{15}$ School culture can support or restrict personal development and changes in school that result from internal development or external factors. The survey of pupils, parents, teachers and school leaders included 12\% of all (general education) schools in Estonia. The study looked for a deeper understanding about the factors that directly or indirectly influenced pupil development based on teachers' perceptions and practices. Various types of schools were described based on school climate, culture, organisational learning, pupil academic coping skills ${ }^{16}$ and well-being, and teacher coping patterns and mind models. ${ }^{17}$

${ }^{13}$ V.-R. Ruus, M. Veisson, M. Leino, L. Ots, L. Pallas, E.-S. Sarv, A. Veisson, 'Õpilaste edukus, toimetulek ja heaolu koolis' [Pupils' success, coping and wellbeing in the school], in M. Veisson, V.-R. Ruus, T. Kuurme (eds.), Eesti kool 21. sajandi algul: kool kui arengukeskkond ja õpilaste toimetulek [Estonian schools at the beginning of the $21^{\text {st }}$ century: school as developmental environment and pupils' coping], Tallinn, Tallinna Ülikooli kirjastus, 2007, pp. 17-58; 'Estonian Schools at the Beginning of the $21^{\text {st }}$ Century. Project School as Developmental Environment and Students' Coping (SF0132495s03, leader M. Veisson),' University of Tallinn, 2003-2007. Available: https://www.etis.ee/Portal/Projects/Display/ce8cbd34-12bd-49ff-a5fe-b962449ae6d6 (accessed 25.01.2017); V.-R. Ruus, E-S. Sarv, L. Pallas, 'Relationships Between Schools' Organisational Climate and the Students' Condition at School, paper presented at the European Conference on Educational Research (ECER), Gent, Belgium, 2007; V.-R. Ruus, M. Veisson, M. Leino, L. Ots, L. Pallas, E.-S. Sarv, A. Veisson, 'Students' Well-being, Coping, Academic Success, and School Climate,' Social Behavior and Personality, vol. 35 no. 7, 2007, pp. 919-936; M. Veisson, M. Leino, L. Ots, V.-R. Ruus, E.-S. Sarv, 'Academic Coping of Students', paper presented at the European Conference on Educational Research (ECER), Crete, Greece, 2004. Available: http://www.leeds. ac.uk/educol/documents/00003895.htm (accessed 15.01.2020).

${ }^{14}$ R. S. Lazarus, S. Folkman, Stress, Appraisal, and Coping, NY, Springer Publishing Company, 1984.

${ }^{15}$ P. Senge et al., Schools that Learn, London, Nicholas Brealey Publishing, 2001.

${ }^{16}$ The key concept of the project was 'coping.' According to Lazarus and Folkman, 'coping' is understood as cognitive and behavioral efforts of an individual aimed at coping with external and/or internal requirements. Skinner and Wellborn argue that pupils' academic coping the way pupils interpret the challenges, drawbacks and difficulties that arise in the process of learning. The coping categories developed by the authors were based on presumption, that coping (and stress) is affected and develops within the interaction between the individual and environment (school climate, school culture). See M. Veisson, M. Leino, L. Ots, V.-R. Ruus, E.-S. Sarv, 'Academic Coping of Students', paper presented at the European Conference on Educational Research (ECER), Crete, Greece, 2004. Available: http://www.leeds.ac.uk/educol/ documents/00003895.htm (accessed 15.01.2020); R. S. Lazarus, S. Folkman, Stress, Appraisal, and Coping, New York, Springer, 1984; R. S. Lazarus, Emotion and Adaptation, Oxford University Press, 1991; E. A. Skinner, J. G. Wellborn, 'Children's Coping in the Academic Domain', in S. Wolchik, I. Sandler (eds.), Handbook of Children's Coping: Linking Theory and Intervention, New York, Plenum Press, 1997, pp. 387-422.

${ }^{17}$ M. Veisson, V.-R. Ruus, T. Kuurme (eds.), Eesti kool 21. sajandi algul: kool kui arengukeskkond ja ópilaste toimetulek [Estonian school at the beginning of the $21^{\text {st }}$ century: School as developmental environment and pupils' coping], Tallinn, Tallinna Ülikooli kirjastus, 2007. 
Theoretical justification and methodology is presented briefly and explanation and research findings are derived mainly from teacher surveys. ${ }^{18}$

\section{School as a developmental environment - organisational culture}

To what extent do schools, as learning organisations and supporters of the development of pupils, differ because of the experience and knowledge of teachers? By focusing on school from the teacher's perspective, we can highlight at least three views.

School as a whole organisation, as a learning and developmental environment for both the teacher and the pupil. For the teacher, this environment is related to professional development and coping, development of individual and collective knowledge, curriculum, and monitoring and supporting pupil development. The concepts of learning organisation ${ }^{19}$ and knowledge creation ${ }^{20}$ are central.

Perception and awareness of pupils and their problems by teachers. The child-centred concept, including pupil learning and democratic participation was a central element of school reform in the 1980s and 1990s and part of the vision of the Estonian national school. ${ }^{21}$ Perception of pupils and their problems is part of the teacher's mental model in Senge's theory. ${ }^{22}$

Teachers as supporters of pupil development, especially academic success. School, it climate and culture, is a support system for the development of the pupil. Perception and awareness by teachers, the nature of cooperation of teachers (supportive or punitive), and the school's 'self-concept' shapes the pupil's developmental environment and cultivates various active or passive coping strategies. The formation and change of school climate and culture are areas of development of the school as a learning organisation.

${ }^{18}$ E.-S. Sarv, Õpetaja ja kool õpilase arengu toetajana. Õpetaja enesest ja koolist [Teacher and school as supporters of pupil development. Teacher about her/himself and about school], Tallinn, Tallinna Ülikool, 2008.

${ }_{19}$ P. Senge, The Fifth Discipline. The Art and Practice of the Learning Organization, New York, Doubleday, 1990; V. J. Marsick, K. E. Watkins, 'Demonstrating the Value of an Organization's Learning Culture: The Dimensions of the Learning Organization Questionnaire', Advances in Developing Human Resources, vol. 5, no. 2, 2003, pp. 132-151.

${ }^{20}$ I. Nonaka,'The Knowledge Creating Company' Harvard Business Review, no. 9, 1991, pp. 96-104; I. Nonaka, H. Takeuchi, The Knowledge-Creating Company: How Japanese Companies Create the Dynamics of Innovation, New York, Oxford University Press, 1995.

${ }^{21}$ E. R. Gretchkina, et al., 'Na puti k novoi shkole: opyt perestroiki narodnogo obrazovanija $\mathrm{v}$ ESSR' [On the way to a new school: the experience of restructuring the national education in the Estonian SSR], Moskva, Pedagogika, 1988, p. 220; E-S. Sarv, 'The "Condition of Postmodernism” and Changes in Estonian Education 1987-1997', in A. Liimets (ed.), Integration und Integrativität als Probleme in der Erziehungswissenschaft, Berlin, Wien, New York, Peter Lang, 2001, pp. 135-152.

22 P. Senge, The Fifth Discipline. The Art and Practice of the Learning Organization, New York, Doubleday, 1990; P. Senge, et al., Schools that Learn, London, Nicholas Brealey Publishing, 2001. 
The soft systems view ${ }^{23}$ has been chosen for the general methodological approach, which is intrinsically close to the ecological view. ${ }^{24}$

From the point of view of a systems approach, there are significant differences between teachers in their perception of pupils, school as an organisation, and school as a developmental environment for pupils. Additionally, there are significant differences between school cultures as learning and knowledge management environments. It is necessary to describe the situation of Estonian education from the teacher's point of view to discover typology of schools.

Nonaka and Senge do not view an organisation as a machine, but rather as a living organism that, quite similar to individuals, can have a collective identity and goals. It is an organisational self-consciousness - a shared understanding of what the organisation is working on, where it is on the road, in which world it wants to exist, and most importantly about how it intends to transform its perception of the world into reality. ${ }^{25}$

The main approaches to learning organisations are Senge's future vision of the system; ${ }^{26}$ Pedler, Burgoyne, and Boydell's ${ }^{27}$ learning-focused; Garvin, Goh's ${ }^{28}$ strategic; and Watkins and Marsick's ${ }^{29}$ integrated approaches. All approaches can apply to schools, but we consider Senge's model as most practical. It addresses the features of school and received attention in the 1990s and 2000s in Estonia.

It is important to note that systems theories scholars emerged in the Soviet Union. In Estonia, Heino Liimets ${ }^{30}$ developed the most influential approach to

${ }^{23}$ P. Checkland, J. Schores, Soft Systems Methodology in Action, Chichester, Wiley, 1990; C. W. Churchman, The Design of Inquiring Systems: Basic Concepts of Systems and Organiza ization, New York, Basic Books, 1971; L. Bertanalaffy, General System Theory, New York, Braziller, 1968; C. Argyris, D. A. Schön, Organizational Learning, Reading, MA, Addison-Wesley, 1978; P. Senge, The Fifth Discipline. The Art and Practice of the Learning Organization, New York, Doubleday, 1990.

${ }^{24}$ U. Bronfenbrenner, 'Developmental Ecology Through Space and Time: A Future Perspective,' in P. Moen, G. H. Elder, Jr. K. Lüscher (eds.), Examining Lives in Context, Washington, DC, American Psychological Association, 1995, pp. 619-647; R. H. Moos, The Human Context: Environmental Determinants of Behavior, N.Y., London, Sydney, Toronto, John Wiley \& Sons, 1976.

${ }^{25}$ I. Nonaka, 'The Knowledge Creating Company, Harvard Business Review, no. 9, 1991, p. 103.

${ }^{26}$ P. Senge, The Fifth Discipline. The Art and Practice of the Learning Organization, New York, Doubleday, 1990.

${ }^{27}$ M. Pedler, J. Burgoyne, T. Boydell, The Learning Company: A Strategy for Sustainable Development, New York, McGraw-Hill, 1991.

${ }^{28}$ D. Garvin, 'Building Learning Organizations', Harvard Business Review, vol. 71, no. 4, 1993, pp. 78-91; S. C. Goh, 'Toward a Learning Organization: The Strategic Building Blocks,' S.A.M. Advanced Management Journal, vol. 63, no. 2, 1998, pp. 15-20.

${ }^{29}$ V. J. Marsick, K. E. Watkins, 'Demonstrating the Value of an Organization's Learning Culture: The Dimensions of the Learning Organization Questionnaire,' Advances in Developing Human Resources, vol. 5, no 2, 2003, pp. 132-151.

${ }^{30}$ Heino Liimets (1928-1989) - Estonian educational scientist, lecturer in logic and psychology, founding member of the Academy of Pedagogy of the USSR, Honorary Doctor of the University of Helsinki and Honorary Doctor of Tampere University. See H. Liimets, 'Õpilase isiksuse areng ja integraalne didaktiline süsteem' [Development of pupil's personality and the integral didactic system], Nõukogude Kool [Soviet school], vol. 6, 1982, pp. 16-21; H. Liimets. Kak vospityvaet 
the system of child environment and development as a whole. His approach was particularly concerned about the perceptions and activities of the teacher. The school as an organisation was not discussed in great detail at the time.

Nonaka and Takeuchi's knowledge management theory and creation of tacit and explicit knowledge provides conceptual support for the pursuit of complex enterprises with high levels of innovation. From this point of view, teaching and learning in school is the processes of knowledge circulation and/ or creation: knowledge acquires new aspects, passes through different states, and passes from person to person, group, community, organisation, etc. ${ }^{31}$

Senge's theory of learning organisation is based on the understanding of the organisation as a dynamic system that is interconnected and in which "five disciplines" of development/learning are perceived - shared vision, personal mastery, development of mental models, teamwork and team learning, and use of systems thinking. ${ }^{32}$

Shared vision is a shared understanding by the members of the meaning and objectives of their activities in an organisation from a distant time perspective. Shared understanding is based on the integration of the individual, group, and the organisation's visions. In Estonia, the culture of vision-creation evolved from two factors: 1) the liberation of schools from ideology and bureaucracy pain from 1987-1996 during Estonian education renewal and 2) the 1996 school Curriculum (1996) and the establishment of a school development strategy plan in 2000. Both formulated the school mission and vision through a stakeholders' agreement.

Personal mastery is the ability to successfully cope with professional activities as well as activities in private life that affect professional practice (e.g. time factor management, recovery, and self-development). Professional mastery of the teacher includes methodological skills required in the contemporary classroom and a broad range of collaborative and communication skills. Pupil observation, peer monitoring, research, and reflection skills are also indispensable.

Mental models require knowledge of one's self and one's peers. Mental models of the members of the organisation are part of the organisation's culture. Mental models focus on awareness of attitudes, perceptions, values, and include reflection and research and attitudes towards them. Mental models are usually not expressed. They work below the level of awareness and often hinder change. One of the aspects of the teachers' mental models is the perception of the pupil, i.e., the imagination of what the pupil is (or 'pupil picture') as well as models of values and 'correct' teaching-learning behavior.

process obučenija? [How the teaching-learning process educates?], Moskva, Znanije, 1982; H. Liimets, 'Iseregulatsioonilt eneseregulatsioonile' [From (spontaneous) self-regulation to intentional self-regulation], Nõukogude Kool, 1983, no. 11, pp. 18-20.

${ }^{31}$ I. Nonaka, H. Takeuchi, The Knowledge-Creating Company: How Japanese Companies Create the Dynamics of Innovation, New York, Oxford University Press, 1995.

32 P. Senge, The Fifth Discipline. The Art and Practice of the Learning Organization, New York, Doubleday, 1990, p. 150; P. Senge, et al., Schools that Learn, London, Nicholas Brealey Publishing, 2001, p. 60. 
Learning in teams results in mutual enrichment (learning from one another) and is a way to develop a shared vision and mental models. Through dialogue, discussion, and more complex cooperative methods, groups transform their collective thinking, learn to mobilise energy and deeds to achieve common goals, and highlight knowledge and capabilities that are greater than the sum of individual members' knowledge and abilities. Formal and informal groups in the school organisation and group dynamics are important for the growth of the organisation's capacity (learning, creating a common vision, curriculum development, etc.), as well as for the membership and recognition of the needs of members of the organisation. Schools have formalised structures, such as classes and methodological committees that work spatially together for a long time, but often they do not form a real learning/research team but are rather a place for coordination of short-term individual activities. It is also important to understand that in a group, there is intensive knowledge circulation and knowledge creation. This process also involves reflection and meta-consciousness, the level of which depends on the group's level of trust and development of the group as a micro-system. In schools, reflective teamwork and learning groups form the basis of development.

The development of systems thinking required consideration of the pastpresent-future dimension, the local level (class, school, or subject matter), and the global level (meanings and effects of an individual phenomenon and activity in the context of a society or a person's life on a local and global scale). The improvement of systems thinking means a) growing theoretical competence (the body of theory - theoretical, conceptualized, and conscious perceptions); b) feedback on activities, and c) complexity, i.e. awareness of the system's inherent internal tendencies and the external context that lead to the growth or stability of the system/organisation over time. Systems thinking in the context of schools must take into account the dynamic and interactive components of pupils, teachers, parents, the class-community, the school as a whole, and individuals. As early as the 1980s and 1990s, Slaughter and Beare emphasised the development of future and systems thinking abilities of the teacher. In the case of the individual, systems thinking also means shifting from 'self-level' to 'our-level'.

Senge's five key areas can be considered aggregate features of learning organisations. Measuring their qualitative 'level' is complicated, but their description can provide an image of a specific learning organisation.

Using the above, general fields and features of the school as a knowledgeseeking learning organisation were derived and covered by combinations of questions and statements in questionnaires for teachers, but partly also for pupils, school leaders and parents as presented in Table $1 .^{33}$

\footnotetext{
${ }^{33}$ E.-S. Sarv, Õpetaja ja kool õpilase arengu toetajana. Õpetaja enesest ja koolist [Teacher and school supporting pupils' development. Teacher about her/himself and about school], Tallinn, Tallinna Ülikool, 2008, pp. 34-35.
} 
Table 1. Features of school as a learning organisation

\begin{tabular}{|c|c|}
\hline Key features & Content/characteristics \\
\hline \multicolumn{2}{|r|}{ Field I - Reflection and research } \\
\hline $\begin{array}{l}\text { 1. Teacher reflection } \\
\text { and research }\end{array}$ & $\begin{array}{l}\text { Self-reflection, self-analysis, the reflection of pedagogical activity at } \\
\text { individual pupil and at the class level, and level of research }\end{array}$ \\
\hline 1.A. Monitoring & Level of monitoring and analysis systems at school \\
\hline \multicolumn{2}{|r|}{ Field II - Key areas of the learning organisation } \\
\hline $\begin{array}{l}\text { 2. Teacher's personal } \\
\text { mastery }\end{array}$ & $\begin{array}{l}\text { General professionalism of teaching (methodological diversity, and } \\
\text { compliance with curriculum, syllabus, and development plan) } \\
\text { Level of development in teacher self-assessment }\end{array}$ \\
\hline $\begin{array}{l}\text { 3. Teacher's mental } \\
\text { models }\end{array}$ & $\begin{array}{l}\text { Teacher values, motivational orientation, readiness for innovation } \\
\text { and self-independence, and level of development } \\
\text { Wider approach also includes teacher concepts of humans and of } \\
\text { learning }\end{array}$ \\
\hline $\begin{array}{l}\text { 4. Team learning and } \\
\text { teamwork }\end{array}$ & Level of formal and informal cooperation and teamwork \\
\hline 5. Shared vision & $\begin{array}{l}\text { Existence of common, shared perspectives (vision, mission), degree } \\
\text { of acceptance and realisation of educational goals }\end{array}$ \\
\hline 6. Systems approach & $\begin{array}{l}\text { Level and development of future-oriented cooperation, both in terms } \\
\text { of the school's main objectives and also in support of individual } \\
\text { zones of proximal development in pupils } \\
\text { Local and global aspects }\end{array}$ \\
\hline \multicolumn{2}{|r|}{ Field III - School climate and culture } \\
\hline $\begin{array}{l}\text { 7. Perceptions of } \\
\text { management by } \\
\text { the teacher }\end{array}$ & $\begin{array}{l}\text { Level of innovation and sustainability of democratisation } \\
\text { Organisation of school life in terms of leadership }\end{array}$ \\
\hline $\begin{array}{l}\text { 7.A. Cultivating } \\
\text { consensus and } \\
\text { common values }\end{array}$ & $\begin{array}{l}\text { Level of shared understanding (including absence of conflict, } \\
\text { jealousy, etc.) and level of acceptance of shared values and their } \\
\text { implementation }\end{array}$ \\
\hline 8. Curriculum & $\begin{array}{l}\text { Participation in development process of curriculum and school } \\
\text { strategic plan } \\
\text { Adoption of the basic ideas and requirements of the curriculum and } \\
\text { development plan } \\
\text { Convinced of their fulfillment }\end{array}$ \\
\hline $\begin{array}{l}\text { 9. Satisfaction and } \\
\text { dedication to teacher } \\
\text { work }\end{array}$ & Level of satisfaction, independence, and commitment \\
\hline \multicolumn{2}{|c|}{ Field IV - Knowledge-management, knowledge-creation } \\
\hline 10. Cooperation & $\begin{array}{l}\text { Degree of teacher-perceived cooperation (including communication } \\
\text { of information), togetherness (including confidence), and of support } \\
\text { among teachers at the school level, individual pupil, and class (or } \\
\text { community). }\end{array}$ \\
\hline 11. Interaction & $\begin{array}{l}\text { Degree of knowledge circulation between teachers and of knowledge } \\
\text { creation at the school level - joint participation in work on curric- } \\
\text { ulum and strategy plan development, mutual learning-teaching - } \\
\text { work with individual pupils and with the class as a whole }\end{array}$ \\
\hline 12. Information flow & Formal level of information distribution, sharing in school \\
\hline $\begin{array}{l}\text { 13. Innovation } \\
\text { and recognition, } \\
\text { appreciation }\end{array}$ & $\begin{array}{l}\text { Support, recognition, and appreciation of innovation, research } \\
\text { (knowledge creation) and active information seeking }\end{array}$ \\
\hline
\end{tabular}


The common goals, culture and spirituality of the school as a community and as an organisation are shaped and realised through the values cultivated in school. At the level of the individual, they are part of the mental models. At the community level, aspects of school culture occur both in a formal setting (lessons, teachers' meetings) and also through informal communication and assessments.

\section{Survey sample and methods}

The research was part of the research project 'School as a developmental environment and pupil coping' that gathered data on various aspects of school life from the main stakeholders - pupils, parents, teachers, and school leaders. The purpose of the research was to clarify what pupil groups are at risk and why.

Analysis of the data sought to find discover what are the strategies and perceptions of the school and teachers about school climate and culture and how do schools and teachers differ as supporters of pupil development and coping. School is a learning organisation and agency for influencing pupil development.

The teacher questionnaire use the Likert scale $(1$ - completely disagree, 2 rather disagree, 3 - more or less agree, 4 - completely agree), and statistical processing of the data used data processing package SPSS 14.0, SPSS 11.0, and MS Excel. Features were derived from the coefficient of validity (Cronbach's alpha) of at least 0.67. Component analysis was used to determine the role of the selected questions in this indicator.

The statement were worded in such a way that acceptance would refer to the desired, positive direction of the fundamental dimensions mentioned in Table 1.

For mapping schools, the ranking of schools was based on an average of the features, typology of teachers, and cluster analysis of schools. The sequencing method (based on teachers' average answers) allowed ranking of schools for multiple aggregates. School rankings were summarised and based on the sum of place codes.

In 2004 during the first phase of the study, teachers $(n=623)$ completed self-assessing questionnaires. The survey involved approximately $12 \%$ of general education schools and $4 \%$ of teachers. The results were generalised for schools and teachers.

In summary, the correlation between all 13 characteristics mentioned in Table 1 was statistically significant $(<0.01)$. Such a strong correlation means that the set of characteristics was comprehensive and, despite the differences between schools and individual teachers, groups of teachers can be used to describe and study the school system and individual schools. 


\section{Findings}

Typology of school as a learning organisation. To analyse school typology, 49 schools, representing each of the counties, cities, stronger and weaker schools (according to three years results of state examinations), and schools working in Estonian, Russian and in both languages with six to 29 respondents and 587 teachers participated.

Based on the characteristics of the culture of learning organisation, a 4-group distribution was sufficient: learning, development-centered schools (25\%); conservative schools (59\%); schools with poor learning ability (8\%); and management-centered schools $(8 \%)$. The general description of these groups is illustrated in Figure 1 and Figure 2.

It became clear that in almost every feature, there were differences between schools in Tallinn and rural areas and schools teaching in Estonian or in Russian. This indicates specific differences in school culture. However, the general typology does not show clear divisions by language or school location.

Figure 1. Grouping of schools as knowledge-managing, learning organisations. Learning, developing schools and conservative schools.

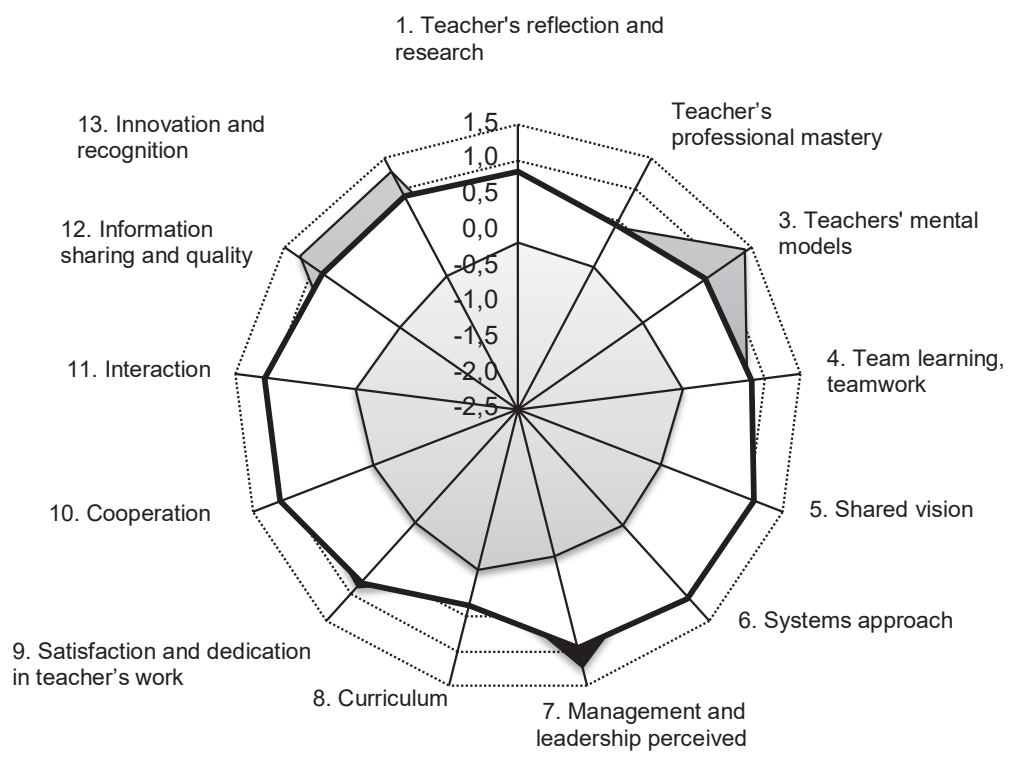

1. Learning, developing school

2. Conservative school

Learning, development-orientated schools (25\%, Figure 1). These schools were characterised by a relatively uniform picture of positive standardised mean values for all features. In seven indicators, the mean was the highest value compared to other clusters. Compared to other features, the value of teacher 
personal mastery, mental models, and curriculum is slightly lower. This refers to some degree of self-criticism or uncertainty (as compared to other features) or higher demands in the view of teacher skills. At the same time, there are features of the learning organisation and knowledge management such as the shared vision and systems approach (view of the future and its transfer to the learning process and common understanding of educational issues) and cooperation and interaction (active position in development of the school and in development of self and pupils) which had a Zscore $>1$. Teachers rated themselves higher as reflective and researching practitioners than in other groups. Therefore, this group of schools can be characterised as learning, development-oriented and well and evenly developed in all fields and believable as child-centred schools.

This group included some special needs schools, one private school, four Tallinn secondary schools (including an "elite" school), two rural schools, and four Russian-language schools. This showed that child-centered learning schools could evolve in a variety of regional environments and have a various pupil contingents.

Conservative schools (59\%, Figure 1). This school group is by far the largest: it also determines the zero level for each attribute and aggregate character by which other schools are rated/described.

The picture of a development-oriented and conservative school group shows that both groups are relatively similar to a 'pattern'. However, the first type of schools is characterised in all areas and in all the attributes of higher in Zscores unlike the other groups of schools. This means that conservative schools have lower beliefs, positivity, satisfaction, dedication, self-esteem, and cooperation as illustrated in Figure 1 and Figure 2. We can, therefore, speak about the culture of a 'broad' and a 'poor' school. Unfortunately, the overwhelming majority of the schools were 'poor'. Often, some of these schools had a school-climate perceived by pupils as indifferent or formal.

Schools with poor learning abilities (8\%, Figure 2). They were viewed as outsiders, conservative and relatively controversial schools, characterised by significantly lower averages in most characteristics than in corresponding indicators of other schools. Teacher personal mastery and curriculum-work was average. Team learning, collaboration, and interaction indicators were particularly low, indicating that in these schools, the level of pre-requisites for learning organisation and knowledge management and knowledge circulation was very low compared to other schools and insufficient to trigger or achieve profound changes on its own. Nevertheless, teachers appreciated their ability to meet curriculum and development plan requirements at a relatively high level. These schools could be considered schools at risk, based on teacher attitudes towards development and change. In these schools, changes took place through external rather than internal processes. In the terminology of the knowledgedriven learning school, these would be conservative schools with relatively poor learning ability. Because teachers in these schools perceived management aspects as very weak (no participation and no positive feedback), these schools could be considered insufficiently guided and managed. 
To achieve real change in these schools, it is possible to rely on the areas perceived by the teachers themselves to become stronger. For example, in one school, the teacher had a personal mastery and faith in fulfilling the curriculum, and in another school - a self-concept related to the study and development plan and future optimism. Some schools had strong reflection and research areas, which is a good basis for the right steps for change.

Nevertheless, a deeper change in mentality and management change seems necessary to increase the ability of these schools to develop. There is also a need for internal and external training to address schools' actual problems incapability of school as an organisation. The latter should be geared towards teamwork and cooperation skills and the specificities of the school in other areas.

Governance/Management-Centered Schools (8\%, Figure 2). Schools in this group are learning-centered with teacher-friendly organisation. Particularly high were four characteristics: teacher mental models, perceptions of management, information and innovation, and recognition. Teachers' personal mastery, teamwork, and collaboration, satisfaction and dedication to teacher work was at the same level of the conservative school group. However, teacher involvement in reflection and research was much lower than in the conservative group.

Figure 2. Grouping of schools as knowledge-managing, learning organisations. Schools with poor learning ability and management centered schools.

1. Teacher reflection and research

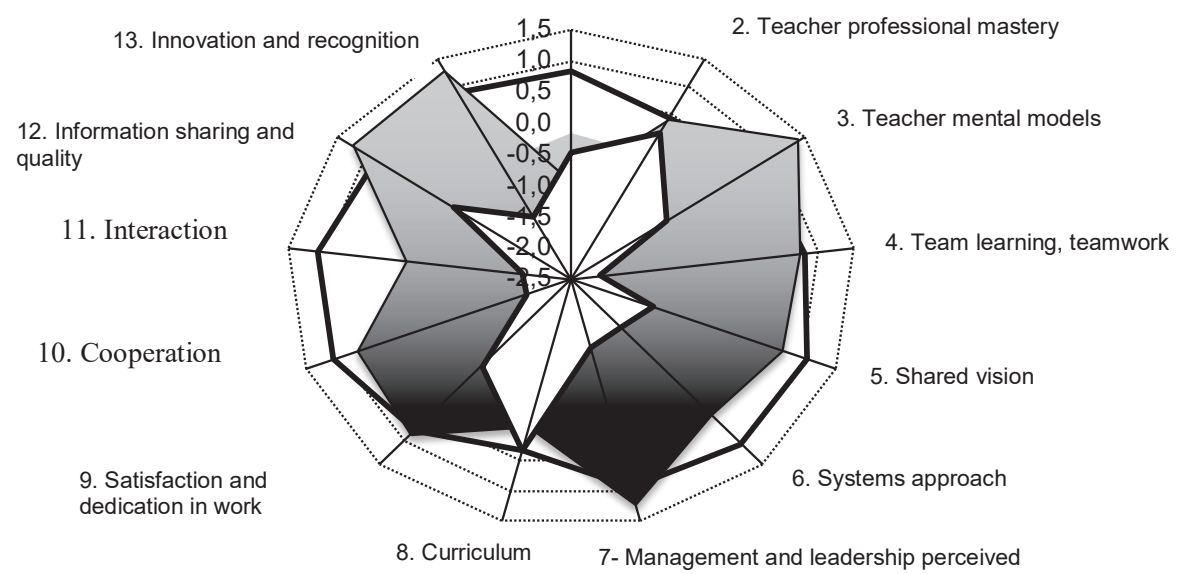

3. School with poor learning ability

4. Management-centered school

Teachers of management-centered schools considered school innovative. They perceived themselves as recognised, participatory, and autonomous and were satisfied and committed: these were schools with a school culture favorable 
to teacher development. However, there were certain disturbances in the field of interaction (active cooperation between teachers for the benefit of pupils and in school and curriculum development aspects). Particularly critical was the state of reflection and research for teachers in this group perceive, which, compared to others, was very weak. This referred to either strong self-criticism or self-centeredness. Regardless, the importance of intensive development and training can be recognised here. From the point of view of the school, this was a well-managed, perhaps even hierarchical and authoritatively leader-based school.

The group of management-centered schools included basic and secondary schools, city and rural schools, and a private and an elite school. These schools showed high satisfaction towards the director (3.88-3.25 in a 4-point system; the average is 3.21).

It should be noted that the inclusion of stronger or weaker schools, based on results of examinations, is not directly related to the fact that the school has stronger or weaker learning cultures (as perceived by the teachers).

Another part of the 2004 study distinguished schools according to teacher mental models and aspects of school-culture and school-climate derived from those models ${ }^{34}$ into four types of schools:

- schools with a positive pupil picture and cooperative orientation of teachers - 30\%;

- neutral, passive schools - 47\%;

- schools with a conflicting pupil picture. There are some indicators of child-centredness, but in general, schools are oriented towards the individual work of the teacher - $9 \%$;

- schools with a pessimistic pupil view, focused on an individual teacher $-13 \%$.

Typologies of schools and teachers according to mental models were described.

The typology of schools from teachers' perspectives of learning organisational culture was connected to the typology of school social climate as perceived by pupils - pupil-hostile; formal-cold; pupil-friendly and demanding; and mediocre. ${ }^{35}$

${ }^{34}$ E.-S. Sarv, Õpetaja ja kool õpilase arengu toetajana. Õpetaja enesest ja koolist [Teacher and school supporting pupils' development. Teacher about her/himself and about school], Tallinn, Tallinna Ülikool, 2008; E.-S. Sarv, M. Leino, L. Ots, L. Pallas, 'Teacher's Views of Students in Estonian Schools', The International Journal of Learning, vol. 15, no. 9, 2008, pp. 169-182.

${ }^{35}$ V.-R. Ruus, et al., 'Õpilaste edukus, toimetulek ja heaolu koolis' [Pupils' success, coping and wellbeing in the school], in M. Veisson, V.-R. Ruus, T. Kuurme (eds.), Eesti kool 21. sajandi algul: kool kui arengukeskkond ja ópilaste toimetulek [Estonian school at the beginning of the $21^{\text {st }}$ century: school as developmental environment and pupils' coping], Tallinn, Tallinna Ülikooli kirjastus, 2007, pp. 43-51. By the request of the school director, researchers did the detail analyses of the school's culture and climate and pupils coping. Usually, the "school picture" was presented at teachers' meeting and used as the basis of the new development plan. 
An interesting contradiction was discovered. Some schools were relatively well-advanced in most or in all of the teacher-based characteristics, but pupils perceived them as unfriendly and cold; they were not happy. This intriguing aspect of school cultures generated some controversial questions and assumptions ${ }^{36}$ and needs further research.

\section{Conclusions and discussion}

Alongside the underestimation of 'soft' values such as creativity in general school culture, there were clear signs of the inadequacy of the principle of equal opportunities, as typologies showed.

When approaching the school as a learning institution, there was a striking difference between schools and the school communities in a collaborative culture. In only a few schools was teamwork culture sensed by all teachers and school staff.

The Estonian study shows a clear relationship between the pupils' feelings and coexistence in corresponding schools, and knowledge-creative, learning school organisational culture and teacher competencies, as some researchers have shown earlier. ${ }^{37}$ Therefore, the internal culture and climate of the school trust, justice, tolerance, and verbal culture - should be further analysed and evaluated, and a great deal of effort is needed to keep the school climate healthy.

The actual school climate and culture can be assessed and understood through systematic research and monitoring of many aspects of school life. The higher the level of systems-thinking among teachers and school leaders, the more adequate the research. Unfortunately, an atmosphere that supports teacher reflection and research was unanimously attributed to teachers in every fourth school only. Nevertheless, $95 \%$ of the respondents thought they had enriched their experience through interaction with other teachers. ${ }^{38}$ This indicated that teachers felt the culture, atmosphere of learning, innovation and mutual enrichment in schools. But, there is marked polarisation between schools in this area. In some schools, learning and exploration are a part of school culture, but in others, the teacher-researcher often perceives him or herself as a first-aid medic.

The teacher's interest in researching topics such as active learning, alternative pedagogy, integration, special education, his/her subject, methodology, and

${ }^{36}$ V.-R. Ruus, E-S. Sarv, L. Pallas, 'Relationships Between Schools' Organisational Climate and the Students' Condition at School, paper presented at the European Conference on Educational Research (ECER), Gent, Belgium, 2007.

37 A. Hargreaves, L. Earl, S. Moore, S. Maning, Learning to Change: Teaching Beyond Subjects and Standards, San Francisco, Jossey Bass, 2001; D. H. Haregraves, 'The Knowledge Creating School,' British Journal of Educational Studies, vol. 47, no. 2, 1999, pp. 122-144.

${ }^{38}$ L. Pallas, 'Kooli õpikeskkond ja õpilaste toimetulek. Ankeet õpetajale. Tabelid' [School as learning environment and pupils' coping. Teacher survey. Tables.], CD-room in E.-S. Sarv, Õpetaja ja kool õpilase arengu toetajana. Õpetaja enesest ja koolist [Teacher and school as supporters of pupil development. Teacher on her/himself and on school], Tallinn, Tallinna Ülikooli kirjastus, 2008. 
pedagogy correlated positively with the teacher's methodological experience even more so with the teacher's degree of commitment. There was also a high correlation between research, educational interest, and how often the teacher spoke with pupils about self-development and the future.

These aspects are the intertwining of collective atmosphere and governance structures - school culture and organisational culture - and the teacher's own professional mastery and personal qualities. And no doubt, in each school there are those who prefer routine, stress-free, smooth situations and perceive innovations and challenges as disturbing and tedious. The components of joy, satisfaction, and happiness are related to physical well-being, the absence of negative emotions, and meaning-wealth. ${ }^{39}$

It is important to note that according to some researchers, the teacher is a relatively conservative and not too creative learner, oriented toward joint activities - even during initial teacher education..$^{40}$ Only about one-third of teachers working in general education have the social readiness to adapt and innovative approach or are innovative in their pedagogical work. ${ }^{41}$ On the other hand, a large number of teachers have quickly acquired computer competences and can successfully adapt to new opportunities at school such as e-schools. This refers to the general willingness and ability of teachers to learn.

\section{Conclusion}

The overall typology of schools shows that a group of schools that is more successful or more positive in all areas is distinguished. However, this group is far from being just the 'elite' schools, as one might expect. No schools with a positive child-attitude had learning disabilities as the learning organisation. The requirement by the national curriculum to create school curriculums and school development plans in cooperation with stakeholders has forced schools to also learn. Approximately half of the schools are capable of learning: some of the elements of this culture are already there, but schools that are poorly managed need external help.

Although distribution of schools of this nature may seem to be quite trivial in the final analysis, we have mapped a great number of schools and can describe schools and aspects of school culture based on a large number of features. Moreover, this analysis offers schools the opportunity to create mapping either by using a questionnaire or as part of professional development.

39 R. Carter, Mapping the Mind, Los Angeles, University of California Press, 1998, p. 103.

${ }^{40}$ E.-S. Sarv, 'Õppimine eesti õpetajate ja üliõpilaste arusaamas 1999. a. ja õppekava' [Learning in the understandings of Estonian teachers and pupils in 1999 and the curriculum], in H. Heinla (ed.) Haridus ja sotsiaalne tegelikkus [Education and social reality], Tartu, Tartu Ülikooli Kirjastus, 2000, pp. 193-205.

${ }^{41}$ S. Kera, 'Õpetaja sotsiaalne valmidus kasvatuse eeldusena' [Teacher's social readiness as a prerequisite for education], Tallinna Pedagoogikaülikooli toimetised. Humaniora A9 [Proceedings of Tallinn Pedagogical University. Series Humaniora A9], Tallinn, 1998, pp. 110-125. 
Understanding differences in school-cultures allows more precise strategic planning of education on all levels from the pupil to the school and to the nation.

There is also a lack of development of a vision through different organisation levels and working groups. This results in the strength of some areas, the weakness of others. The overview and coordination of the value chain, value network, or hierarchy is poor.

In many schools, individual success, individual failure, and teaching of subjects separately predominates in place of a systems approach. This means strengthening intra-school competition (although both school leaders and teachers declare cooperation), which also affects pupils. So, the school will indirectly shape society over the next decades as a competitive society.

To become a learning and knowledge-creative school and survive as such often requires analysis and re-development of existing school culture. A democratic and human(istic) society needs a democratic and humancentered school culture. 